\title{
Understanding the Plant Aphid Interaction: A Review
}

\author{
Waghmare Kranti, Ghayal Nivedita, and Mahesh Shindikar
}

\section{ABSTRACT}

The interaction between plant-aphid is phenomenal and complex. Aphids possess efficient mouthparts which feed on plant sap intensively. Adaptation to host plants and successful feeding is achieved through the strategic ability of aphids to reproduce sexually and asexually (parthenogenesis). Aphid infestation damages the plant in diverse ways and induces plant defense. Though plant elicit direct and indirect defense to resist aphid feeding, the effectiveness of plant resistance depends largely on the aphid infestation rate and quality of the host plant. To control aphid infestation and plant damage, dependency on insecticides is undesirable due to insecticidal resistance of aphids and environmental pollution. The approach towards the development of the genetically engineered crops which are aphid resistant can be the considerable potential to aphid control.

Keywords: host selection, feeding injury, plant-aphid interaction, plant defense.

Published Online: November 30, 2021

ISSN: 2684-5199

DOI : $10.24018 /$ ejbio. 2021.2 .6 .294

Waghmare Kranti*

A K Department of Biodiversity, M E S Abasaheb Garware College, Pune, India.

(e-mail: waghmare.kranti87@gmail.com) Ghayal Nivedita

A K Department of Biodiversity, M E S Abasaheb Garware College, Pune, India.

(e-mail: gnivedita_ghayal@ rediffmal.com) Shindikar Mahesh

Department of Applied Science, College of Engineering Pune, India.

(e-mail: maheshshindikar@gmail.com)

*Corresponding Author

\section{INTRODUCTION}

Aphids are major group of herbivores which belong to order Hemiptera and superfamily Aphiditae. As a crop pest aphids affect the agro economy by excessive feeding on plant phloem and serving as the vectors of various plant diseases. There are almost 4000-5000 aphid species are described, among them 250 are important agricultural pest which vary with their host plants (Blackman \& Eastop, 1994; Blackman \& Eastop, 2000; Kumar, 2019). The extent of being adapted to tropical environment to subtropical environment make them widely distributed throughout the world and impact badly on agro economy (Poirié \& Coustau, 2011). This extent of wide range of availability, agricultural conditions, diversity of crops, variations in population size and in the crop areas damage make researchers difficult to give a precise assessment of total global economic loss (Dedryver et al., 2020) The reason of being able to limit the productivity lies in the amazing biological features and population strategies. These phytophagous insects possess long slender mouthparts which pierce a tender plant and suck plant sap which ferries sugar and other nutrients. This specific habit of feeding is highly supported by the high reproductive potential. Aphids undergo parthenogenesis and viviparity showing the maximum intrinsic rate. Conserving the energy in reproduction, possession of needle-like structure of stylet capable of piercing plant cell walls and acting as a vector to deliver viruses into host cell (Ng \& Perry, 2004) make them enough to exploit agricultural environment. Aphid feeding on plants and reaction of the plant as defense make the complex processes involved in plant aphid interaction. This review understands and summarizes this co evolutionary relation between plant and aphids (Fig. 1).

\section{HoSt SELECTION BY APHIDS}

The interaction of aphid with the plant starts with the host selection process. The host selection is a complex process involving various steps like host location, host acceptance, feeding of phloem or with rejection (Ernesto, 1997). Aphids are highly selective insects in their selection of plants as host plants. Sensory and behavioral mechanisms help aphids in decisions of host selection process comprise of vision, olfaction, mechano-sensation, and gustation (Verdugo et al., 2106; Powell et al., 2006). Sensory cues start playing the role with the process of host location. Aphids get attracted towards yellow and green colored leaves other than autumnal red leaves (Döring et al., 2009). Here, though aphids are poor flyers but they locate the plant for landing using visual cues but at the short distance, here plant volatiles play a role (Döring, 2014; Bernays, 2001). The selection of landing on a specific plant occurs due to visual and olfactory cues. As aphids land after locating the host, they assess the initial plant contact and surface cues before stylet penetration. After landing, antennal movement of aphids judges the physical appearance of the plant surface. Chemosensory and mechano receptors of antennal hair detect the color, wax, trichome, texture of the plant surface, thickness of leaf (Mandal et al., 2020). After dealing with the plant surface, probing i.e., plant penetration process is initiated with insertion of long stylet. Style is made of two long mandibules and two inner maxillae which form food and salivary canal (Giordanengo et al., 2010) (Pettersson et al., 2018; Uzest et al., 2010). Stylet penetrates beyond epidermis sampling the sap for gustatory discrimination. The longer Sieve elements sucking may 
represent the host acceptance. Aphids utilize the surface cues present on the plant to decide whether to feed and or oviposit (Walling, 2008). In phloem phase after sap sampling aphid may reject the plant depending on upon its quality. Level of nitrogen, water content, defensive components, trace elements, carbon comprise the quality of a host plant (Mandal et al., 2020). The acceptance leads to sustain feeding which ultimately starts damaging the plant.

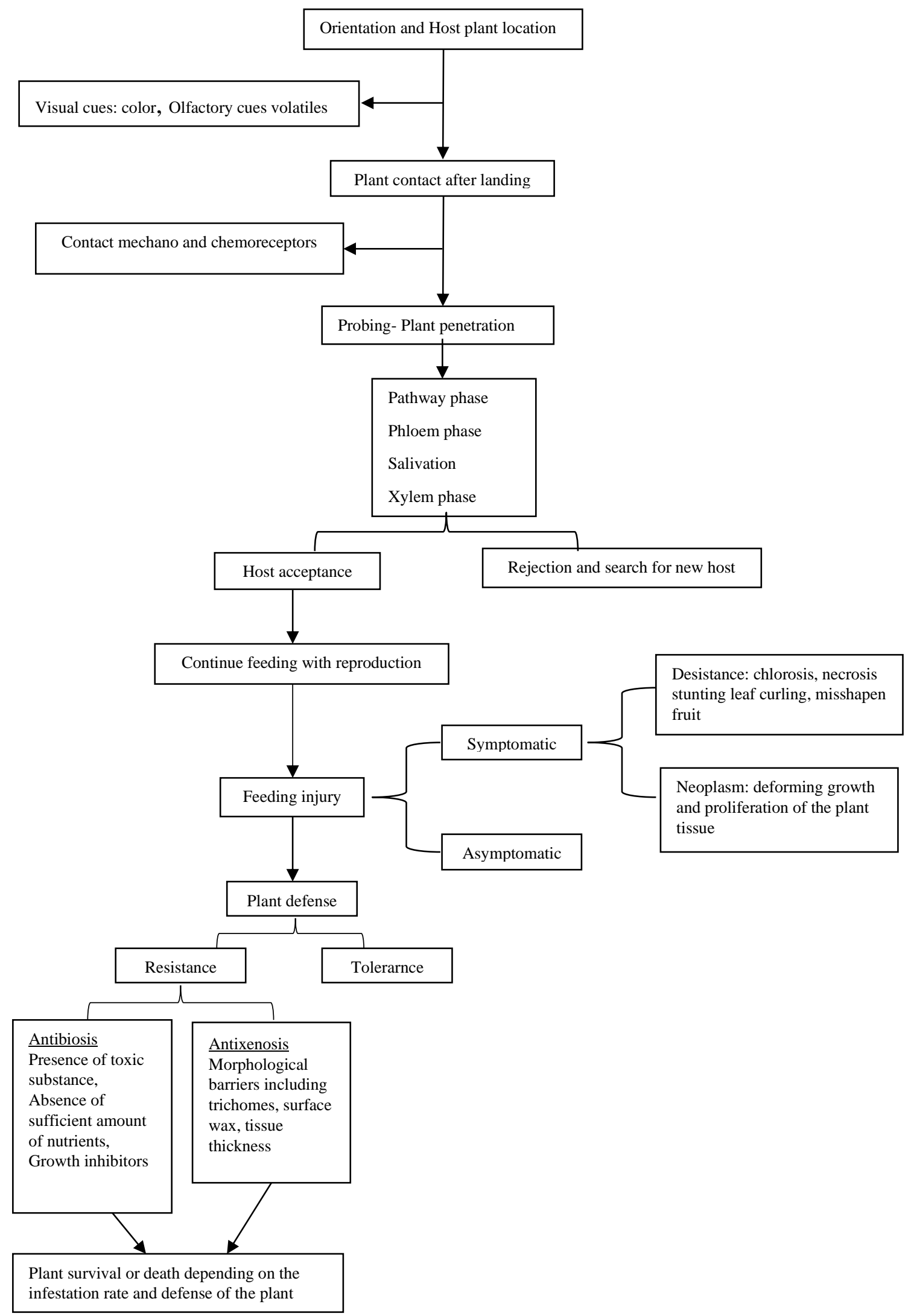

Fig. 1 shows the plant insect interaction starting with the host selection process followed by feeding. Aphids show feeding injury which is symptomatic and asymptomatic. This process of integration may end on plant defense and aphid counter defense of counter adaptations depending upon the quality of the host plant and aphid infestation rate. 


\section{APHID REPRODUCTIVE STRATEGY}

Higher reproductive abilities make aphids causing maximum loss in plants. Aphids start reproducing during host acceptance process as, parturition cues are mostly detected early in the stylet pathway (Powell et al., 2006). Aphids reproduce parthenogenetically followed by viviparity (Miura et al., 2003), phenomenon of telescopic generation where newly born offspring is already pregnant allows rapid parturition on the selected host plant and start sucking the plant sap and grow rapidly (Powell et al., 2006). This is the mostly adopted method of reproduction while colonizing on new plant (Giordanengo et al., 2010). Reproduction without male increases the intrinsic rate ( $\mathrm{rm}$ ) of the population. The reproduction in aphids is season specific. In autumn sexual reproduction takes place, where oviparous female opulate with male aphid and lay eggs. Whereas in spring and summer parthenogenetic female gives birth to larvae (Murano et al., 2018; Ogawa \& Miiura, 2014). On the basis of utilization of host plants, reproductive strategy of aphids varies. Host altering i.e., heterocious reproduce sexually on primary host by laying eggs. These eggs hatch in spring giving birth to fundatrices or stem mother, wingless morphs which further gives birth to fundatrigenia generation. Later reproduction of spring migrants, winged morphs fly to secondary host where they reproduce parthenogenetically. Here several generations are produced of winged male and gynoparae are produced then they migrate to primary host (Kumar, 2019; Hardie, 2018). In other hands non host altering species i.e., monoceous species remain on the same plant throughout the year showing winged or wingless polyphenism in summer. Whereas in autumn male and oviparae are produced by same mother (Thomas et al., 2012). Depending on the breadth of their host range aphids have been classified as monophagous, oligophagous, polyphagous, pantophagous aphids (Eastop, 1973). The reproductive strategies are mostly factor dependent. These alternations of reproductive modes make them worst impacting badly on their feeding behavior and thus on plant health.

\section{APHID FEEDING BEHAVIOR}

Sustained ingestion after host acceptance determines the rate of infestation and further causes significant changes in plants. Host acceptance further leads to utilization of cell contents or phloem and or xylem sap with their piercing mouthparts. The modified mouthparts are able to probe into plant tissue and feed from sieve element. While feeding from SE aphid secret gelling saliva which hardens to form a sheath (Nalam et al., 2018; Miles, 1999; Cherqui \& Tjallingii, 2000; Will et al., 2013). This tactic facilitates the smooth movement of the stylet in intracellular spaces and also lowers the threat of wounding response by the host plant and prevents the induction of defense responses (Kumar, 2019; Will \& Van Bel, 2006). Along with gelling saliva aphid produces watery saliva. The gelling saliva is viscous, dense, and proteinaceous (Guerrieri \& Digilio, 2008) and contains complex carbohydrates, phospholipids and protein sap that appear to be consistently represented in the sheath saliva in number of aphid species (Miles, 1999) (Cherqui \& Tjallingii, 2000). The watery saliva, which is secreted intracellularly, either when the stylets briefly puncture cells during probing or immediately and during sap ingestion (Will et al., 2013). Aphids take help from gustatory cues to make decision to continue feeding on plant or not. This happens when aphids put stylet into contents of epidermal and mesophyll cells while entering into SE through intracellular spaces (Nalam et al., 2018). This release triggers the plants first line of defense. Plant surface characteristics such as hairiness and the structure of epicuticular wax may reject aphid walking. Presence of trichomes hampers the movement of aphids, which affects the stylet insertion, indirectly the host selection process (Guerrieri \& Digilio, 2008) Still some aphids manipulate this defense such as M. mentzeliae is capable of feeding on M. Pumila manages to avoid entrapment by trichomes by walking slowly which does and by having tipped legs it is able to somehow to tiptoe through the thorns (Eisner et al., 1998). Further phloem feeding may lead to dehydration of the insect due to presence of large concentration of carbohydrates in the sap which created an osmotic pressure (Walling, 2018). Continuous feeding on phloem makes plant weak and lead to alteration of plant hormone along with induction of defense mechanism. Nonetheless, along with secretion of saliva aphids also secrete waste products of phloem ingestion onto plants in the form of honeydew. This honeydew secretion can also modulate host defense and also have lethal effects on plant. Continuous feeding on plant leads to feeding injuries.

\section{APHID FEEDING INJURY}

Consumption of phloem sap by piercing mouthparts affects plant physiology in diverse ways. The phases of feeding including stylet probing, salivation, and ingestion of sap damage the plant diversely. Plant damage depends on aphid infestation rate, developmental stage of the plant of the plant when infested and the sensitivity of each stage to sieve diversion (Dedryver et al., 2020). Stylet penetration and withdrawal injure the plant. The sieve diversion causes extensive apparent symptoms where some damages are asymptomatic (Quisenberry \& NI, 2007). These symptomatic and asymptomatic damages reduce the growth and development of the plant and eventually death. Moreover, intracellular penetration causes more ultrastructural damage to plant tissue than does intercellular penetration (Goggin et al., 2018). Plant response to aphid damage is sometimes asymptomatic i.e., plant does not show any aberrations while symptomatic is apparent visible damage. Symptomatic damage varies from desistance (Chlorosis, necrosis, stunting, and leaf curling) to neoplasm (abnormal structures) (Goggin et al., 2018). The Black Pecan aphid causes chlorotic feeding damage to pecan foliage which encourages aphid settling and nymphal growth (Cottrell et al., 2009). Neoplasm deforms the new growth, strongly disturbs the cell multiplication around the feeding point and proliferate the plant tissue into abnormal structure (Dedryver et al., 2020). Gall formation is the unique group of interaction between aphids and host plants where it is species specific and induced by aphid with a different shape, size, and galling sites (Kmieć et al., 2014) and can be formed on only young plant organs (Wool, 2004). The biological complexity of galls with aphids promises the protection from natural enemies and insecticide (Guerrieri \& Digilio, 2008). 
TABLE I: APHIDS ATTACKING CROPS, FEEDING INJURIES AND APHID TRANSMITTED VIRUSES

\begin{tabular}{|c|c|c|c|c|}
\hline Sr. no. & Aphid & Host plant & Feeding injury & Virus \\
\hline 1. & $\begin{array}{l}\text { Dysaphis plantaginea } \\
\text { (Parsserini) }\end{array}$ & Apple fruits & $\begin{array}{l}\text { Leaf/ fruit deformation, localized tissue } \\
\text { damage }\end{array}$ & D. Plantaginea virus \\
\hline 2. & L. erysini & Mustard plant & Curling of leaves, flower and pods & Common mosaic virus \\
\hline 3. & $\begin{array}{l}\text { Myzus } \\
\text { (Davidson) }\end{array}$ & Peach & Leaf curling to cigar shape & Plum pox virus \\
\hline 4. & $\begin{array}{l}\text { Russian wheat aphid } \\
\text { (Diuraphis noxia) }\end{array}$ & $\begin{array}{l}\text { Wheat } \\
\text { Barley }\end{array}$ & $\begin{array}{l}\text { Leaf rolling } \\
\text { Whitish, yellow and red leaf markings, leaf } \\
\text { decoloration }\end{array}$ & Barley yellow dwarf virus \\
\hline 5. & $\begin{array}{l}\text { Oat aphid } \\
\text { (Rhopalosiphum padi) }\end{array}$ & $\begin{array}{l}\text { Oats } \\
\text { Wheat } \\
\text { Barley }\end{array}$ & $\begin{array}{l}\text { Reduced tillering } \\
\text { Stunting }\end{array}$ & Barley yellow dwarf virus \\
\hline 6. & $\begin{array}{l}\text { Green peach aphid } \\
\text { (Myzus persiae) }\end{array}$ & $\begin{array}{l}\text { Canola } \\
\text { Lupin } \\
\text { Pulses } \\
\text { Tobacco } \\
\text { Pepper }\end{array}$ & $\begin{array}{l}\text { Leaf distortion, wilting of cotyledons, leaf } \\
\text { senescence, seedling death }\end{array}$ & $\begin{array}{l}\text { Beet western yellow virus } \\
\text { Cucumber mosaic virus } \\
\text { Pea seed borne mosaic virus }\end{array}$ \\
\hline 7. & $\begin{array}{lr}\text { Cabbage } & \text { aphid } \\
\text { (brevieoryne brassicae) }\end{array}$ & $\begin{array}{l}\text { Canola } \\
\text { Crutiferous forage } \\
\text { crops }\end{array}$ & $\begin{array}{l}\text { Reducing pod set, pod fill, reduced grain } \\
\text { quality, late flowering }\end{array}$ & $\begin{array}{l}\text { Beet western yellow virus } \\
\text { Cucumber mosaic virus }\end{array}$ \\
\hline 8. & $\begin{array}{l}\text { Turnip aphid } \\
\text { (Lipaphis } \\
\text { brassicae) }\end{array}$ & $\begin{array}{l}\text { Canola } \\
\text { Crutiferous forage } \\
\text { crops }\end{array}$ & $\begin{array}{l}\text { Reducing pod set, pod fill, reduced grain } \\
\text { quality, late flowering }\end{array}$ & $\begin{array}{l}\text { Turnip mosaic virus } \\
\text { Cucumber mosaic virus }\end{array}$ \\
\hline 9. & Blue green aphid & $\begin{array}{l}\text { Lupins } \\
\text { Lucerne }\end{array}$ & $\begin{array}{l}\text { Wilting, stunted growth, leaf curling, leaf } \\
\text { drop }\end{array}$ & $\begin{array}{l}\text { Beet western yellow virus } \\
\text { Cucumber mosaic virus }\end{array}$ \\
\hline 10. & $\begin{array}{l}\text { Cow pea aphid } \\
\text { (Aphis craccivora) }\end{array}$ & $\begin{array}{l}\text { Legume } \\
\text { Faba beans } \\
\text { Lentils }\end{array}$ & $\begin{array}{l}\text { Yellowing/ whitening of leaf veins, wilting } \\
\text { of leaves and plant death, leaf bunching, } \\
\text { stem twisting }\end{array}$ & $\begin{array}{l}\text { Alfalfa mosaic virus } \\
\text { Alfalfa leaf curl virus } \\
\text { Beet western yellow virus }\end{array}$ \\
\hline 11. & $\begin{array}{l}\text { Pea aphid } \\
\text { (Acyrthosiphon pisum) }\end{array}$ & $\begin{array}{l}\text { Faba beans, } \\
\text { Lucerne, chickpea }\end{array}$ & $\begin{array}{l}\text { Leaf deformation, wilting, yellowing, } \\
\text { stunting, leaf curling, leaf drop, reduced } \\
\text { dry matter }\end{array}$ & $\begin{array}{l}\text { Cucumber mosaic virus } \\
\text { Beet western yellow virus } \\
\text { Cucumber mosaic virus } \\
\text { Pea seed borne mosaic virus } \\
\text { Alfalfa mosaic virus }\end{array}$ \\
\hline
\end{tabular}

Ryckebusch et al., 2020; Gálvez, 1990; Aphid-transmitted viruses in vegetable crops; Contingency Plan, 2011; Gildow, 1983; Halbert et al., 1994; Adachi et al., 2018; Ghosh et al., 2017; Katis et al., 2007; Aphids on Cruciferous Crops Identification and Management; Goggin et al., 2018; Dedryver et al., 2020; Kumar, 2015; Eisner et al., 1998.

In addition to these injuries, honeydew causes indirect feeding damage to plants from physical level to chemical level. Honeydew secretion in aphids causes development of Black sooty mold on leaf that interferes with normal photosynthetic activity (Dedryver et al., 2020). That not only blocks stomata, interfering the gaseous exchange but also leads to leaf fall (Kumar, 2019). Honeydew also creates a mutualism in ants, parasitoid wasp with aphids (Tena et al., 2018). The secretion of honeydew creates a symbiotic relationship between aphids and ants, which further protects aphids from their natural enemies (Mandal et al., 2020). The black bean aphid A. fabae is regularly tended by honeydew collecting ants and benefits then from mutualism; in return ants defend the aphid from natural enemy (Fischer et al., 2005). Furthermore, it suppresses the jasmonic acid to reduce plant defense activity (Schwartzberg \& Tumlinson, 2014). One of the factors that affect the feeding injury is aphids acting as a vector for plant viruses. During feeding aphid simultaneously ingest sap contents and infect saliva which can contain viruses if the aphid has fed previously on virus infected plant (Stevens \& Lacomme, 2018). This virus transmission takes down the plant machinery by manipulating and suppressing the plant defense showing various symptomatic and asymptomatic damages (Table I).

\section{Plant DefEnse}

Aphid feeding causes alterations in their host plant and eventually death. To fight against aphid attack plants have developed a defensive mechanism which is elicited during sap sampling itself. Plant characteristics such as thickness of cuticle, presence, or absence of waxy layer above the leaf surface, trichomes and nutritional status of plants greatly influence aphid species to select their suitable host (Mandal et al., 2020). This defensive system is guided by various forms: antixenosis, antibiosis and tolerance. Where antixenosis and antibiosis are fall under resistance category in which plant uses chemical and physical mechanisms to reduce herbivory (Verdugo et al., 2016). Antixenosis can be the important mode of resistance by reducing the host selection machinery of the aphid (Ogawa \& Miiura, 2014).

Disturbing the host selection process adversely impacting insect behavior to find sieve element deters infestation (Pettersson et al., 2018). Antibiosis i.e., chemical, and physical defense of the plant affect the growth, development and or reproduction of the insect. Constitutive presence of trichomes, thorns, epidermal wax, cell wall thickness, color prevents the feeding activity (Guerrieri \& Digilio, 2008). Epicuticular wax from plant act as aphicide against grain aphids (Wójcicka, 2015). Trichomes resemble hair like structures that have possibility to consist of different types: non glandular, glandular, curly, straight, unicellular, multicellular, hooked and simple (Werker, 2000), (Pritchard, 2017). High density of glandular trichomes show high 
resistance to green peach aphid (Antonio da Silva et al., 2019). These trichomes also contribute to chemical defense along with acting as a physical barrier to aphid movement on the plant (Louis et al., 2012). Likewise, in solanum berthanault Hawkes whose glandular hairs produce (E) Farnesene the aphid alarm hormone that prevents the colonization by inducing dispersal behavior in winged aphids (Guerrieri \& Digilio, 2008).

There are probably different factors other than physical barriers that cause induced resistance such as changing in quality of amino acid, jasmonic acid and salicylic acid which hinders the feeding mechanism (Amiri et al., 2017) by contributing to signaling associated with plant defense (Nalam et al., 2018). Volatiles including alkaloids, phenols, terpenoids inhibits the oviposition and attract natural enemy (Sánchez-Sánchez \& Morquecho-Contreras, 2017). Amino acids and other secondary metabolites influence the ability of survive and reproduction of melon aphid (Daryanto et al., 2017). Apart from antixenosis and antibiosis, tolerance minimizes the plant damage and recover the plant (Louis et al., 2012), (Nalam et al., 2018). In order to tolerate the aphid infestation, plants reduce photosynthetic activity by decreasing total chlorophyll and carotenoid content (Koch et al., 2016). This defensive system depends upon the quality of the host plant and infestation rate.

\section{FutUre AsPect of Plant APHID INTERACTION}

Plant aphid interaction is the co-evolutionary process where both are biotic and abiotic factor dependent. There are many ways to control aphids including chemical pesticides along with IPM. Though chemical insecticides are found lethal against aphids they have their own limits as they also have harmful effects on environment. It is also necessary to overcome the limits of traditional management ways. To lower the feeding injury many researchers are studying plant defense system to have genetic control on aphids. Testing genetically engineered varieties against aphids provides new insights in aphid management. The innovative genetic strategies, study of interaction between bio pesticides and plants can offer the possibility of the development in an appealing avenue of future aphid plant interaction research.

\section{ACKNOWLEDGMENT}

The authors are thankful to Principal and Head, A. Kulkarni Department of Biodiversity, M. E. S. Abasaheb Garware College for providing the facilities of this research.

\section{REFERENCES}

[1] Adachi S, Honma T., Yasaka R., Ohshima K., Tokuda M. et al. Effects of infection by Turnip mosaic virus on the population growth of generalist and specialist aphid vectors on turnip plants. PLOS ONE. 2018;13(7): 2018.

[2] Amiri M, Mansouri S. M., Mehrparvar M., et al. Attacks by Safflower Aphid, Uroleucon carthami (Hem.: Aphididae), And Cotton Bollworm, Helicoverpa armigera (Lep.: Noctuidae), Induce Resistance to Subsequent Safflower. 2017.

[3] Antonio da Silva A., Carvalho R., Carvalho Andrad M., Zeist A., Viela de Resende J., Muluf W., et al. Glandular trichomes that mediate resistance to green peach aphid in tomato genotypes from the cross between S. galapagense and Slycopersicum. Genetics and plant breeding Acta Scientiarum Agronomy. 2019;41(e42704).

[4] Aphids on Cruciferous Crops Identification and Management, Texax A and M Agrilife Extension, .T-X. Liu and A. N. Sparks, Jr.

[5] Aphid-transmitted viruses in vegetable crops, Queensland: Denis Persley and Cherie Gambley,Department of Employment, Economic Development and Innovation,(DEEDI).

[6] Bernays, E. (2001). Neural limitations in phytophagous insects: implications for diet breadth and evolution of host affiliation. Annu. Rev. Entomol., 46,703-727.

[7] Blackman R. L. \& Eastop V. F. (1994) Aphids on the world's trees: an identification and information huide, Walingford $\mathrm{UK}$ : $\mathrm{CAB}$ International.

[8] Blackman R. L. \& Eastop V. F. (2000) Aphids on the world's crops: an identification and information guide, 2nd ed. Chichester UK: Wiley.

[9] Cherqui, A., \& Tjallingii, W. F. (2000) Salivary proteins of aphids, a pilot study on identification, separation and immunolocalisation. Journal of Insect and physiology, 46:1177-1186.

[10] Contingency Plan - Aphid transmitted viruses, s.l.: Plant Health Australia, 2011.

[11] Cottrell T. E., Wood B. W., NI X. et al. Chlorotic feeding injury by the black pecan aphid (Hemiptera:Aphididae) to pecan foliage promotes aphid settling and nymphal development. Environ. Entomol, 2009;38(2):411-416.

[12] Daryanto A., Syukur M., Hidayat P. et al. Antixenosis and antibiosis based resistance of chili pepper to melon aphid. Journal of Applied Horticulture. 2017;19(2):147-151.

[13] Dedryver C. A., Anne Le Ralec, Fabre F. R., et al. The conflicting relationships between aphids and men:A review of aphid damage and control strategies. Comptes Rendus Biologies, 2020; 333:539-553.

[14] Döring, T. F., Archetti, M., Hardie, J. et al. (2009) Autumn leaves seen through herbivores eyes. Proceedings of the royal society london, London B 276.

[15] Döring, T. F. (2014). How aphids find their host plants and how they don't? Ann. Appl. Biol.165,3-26.

[16] Eastop, V. F. (1973) Biotypes of aphid. In L. A. D Perspectives in aphid biology, Aukland: Entomological society of New zealand. Pp. 40-41.

[17] Eisner, T., Eisner, M., Hoebeke, E. R. et al. (1998). When defense backfires: Detrimental effect of a plant's protective trichomes on an insect beneficial to the plant. Proc. Natl. Acad. Sci. USA, 95,44104414.

[18] Ernesto, P. C. (1997). Aphid-plant interactions at phloem level, a behavioural study". Wageningen: s.n.

[19] Fischer M. K., Völkl W., Hoffmann K. H., et al. Honeydew production and honeydew sugar composition of polyphagous black bean aphid, Aphis fabae (Hemiptera: Aphididae) on various host plants and implications for ant-attendance. Eur. J. Entomol. 2005;102:155-160.

[20] Gálvez, G. E. (1990) Aphid transmitted viruses. s.1.:CIAT.

[21] Ghosh A., Chakrabarti S., Mandal B., Krishna Kumar N. K. et al. Aphids as Vectors of the Plant Viruses in India. A Century of Plant Virology in India. 2017;515-537.

[22] Gildow, F. E. (1983). Biology of Aphid Vectors of Barley Yellow Dwarf Virus and the Effect of BYDV on Aphids. The United Nations Development Programme and CIMMYT, Mexico.

[23] Giordanengo P., Brunissen L., Rusterucci C., Vincent C., Aart van Bel, Dinant S., Girosse C., Faucher M., Bonnemain J. et al. Compatible plant-aphid interactions: How aphids manipulate plant responses. Comptes Rendus Biologies. 2010;333:516-523.

[24] Goggin F., Quisenberry S. S., Ni X. et al. (2018). Feeding injury. In R. H. Helmut F. van Emden, (Eds), Aphids as crop pests Oxfordshire: CAB International. 2018:303-316.

[25] Guerrieri, E., \& Digilio, M. C. (2008). Aphid-plant interactions: a review. Journal of Plant Interactions, 3(4),223-232.

[26] Halbert S. E., Mink G. I., Silbernagel M. J., Mowry T. M. et al. Transmission of bean mossaic virus by cereal aphids. Plant Disease. 1994;78:983-985.

[27] Hardie, J. (2018), Life cycles and polyphenism. In R. H. Helmuf \& F Van Emden (Eds), Aphid as crop pests Oxfordshire: CAB International. pp. 81-98.

[28] Katis, N. Titsipis, J. Stevens, M. Powell, G. (2007) Transmission of Plant Viruses. In H. F. Van Emden \& R. Harrington (Eds.), Aphids as crop pests Oxford: CAB International. pp.353-390.

[29] Kmieć K, Kot I., Sytykiewicz H., Golan K., Górska-Drabik E., Czerniewicz P., Lagowska B. et al. (2016). Aphids' galls - damage or decorative value of host plants? International Scientific Horticulture Conference Slovak University of Agriculture in Nitra, Nitra.

[30] Kumar, S. (2019). Aphid-Plant Interactions: Implications for Pest Management. In Vegetation - Natural and Cultivated Vegetation in a Changing World, s.1.:Intech open, pp. 1-10. 
[31] Kumar, S. (2015). Relative abundance of turnip aphid and the associated natural enemies on oilseed brassica genotypes. Journal of Agricultural Science and Technology. 17,1209-1222.

[32] Koch K. G., Champman K., Louis J., Heng-Moss J. T., Sarath G. et al. Plant tolerance: A unique approach to control Hemipteran pests. Frontiers in plant science. 2016;7.

[33] Louis J., Singh V., Shah J. et al. Arabidopsis thaliana-Aphid Interaction. American Society of Plant Biologist. 2012.

[34] Mandal P., Mondal F., Hossain M. et al. Factors Influences Selection and Adaptation of Aphid to their Host Plant. Journal of Plant Sciences and Crop Protection. 2020.

[35] Miles, P. W. (1999) Aphid saliva. Biological reviews, 74:41-85.

[36] Miura T., Braendle C., Alexander S., Sisk G., Kumbhampati S., Stern D., et al. A comparison of parthenogenetic and sexual embryogenesis of the pea aphid Acyrthosiphon pisum (Hemiptera: Aphidoidea). Jez B Molecular and developmental evolution. 2003;295(B)(1).

[37] Murano K., Ogawa K., Kaji T., Miura T. et al. Pheromone gland development and monoterpenoid synthesis specific to oviparous females in the pea aphid. Zoological letters. 2018;4(9).

[38] Nalam V., Louis J., Shah J., et al. Plant defense against aphids, the pest extraordinaire. Plant Science. 2018;279: 96-107.

[39] Ng, J. C. K ., \& Perry, K. L. (2004). Transmission of plant viruses by aphid vectors. Molecular Plant Pathology, 5, 505-511.

[40] Ogawa, K., \& Miiura, T. (2014). Aphid Polyphenisms: trans generational development regulation through viviparity. Frontiers in Physiology, 5.

[41] Pettersson, J., Tjallingii, W. F., Hardie, J., (2018) Host - plant selection and feeding. In: R. H. Helmut F. van Emden (Eds.), Aphid as crop pests. Oxfordshire: CAb Interantional. Pp. 173-190.

[42] Poirié, M., \& Coustau, C. (2011). The evolutionary ecology of aphids' immunity. ISJ,8,47-255.

[43] Powell G. , Tosh C. R., Hardie J. et al. Host plant selection by aphids: Behavioral evolutionary, and applied perspectives. Annual Review of Entomology. 2006; 51:309-330.

[44] Pritchard, S. R. (2017). Impact of soybean trichomes on Aphis glycines (Hemiptera: Aphididae) and their interaction with natural enemy abundance and predation, Ames, Iowa: Iowa State University.

[45] Quisenberry, S. S., \& NI, X. (2007) Feeding injury. In H. F. \&. H. R. Van Emden (Eds), Aphids as crop pests Oxford UK: CAB International.

[46] Ryckebusch, Sauvion F., Granier N., Roumagnac M., Peterschmitt M., et al. Alfalfa leaf curl virus is transmitted by Aphis craccivora in a highly specific circulative manner. Virology. 2020; 546:98-108.

[47] Saeidi, K. (2020). Plant resistance to the safflower aphid, uroleucon carthami (theobald) (homoptera:aphididae) in safflower genotypes. Mun. Ent. Zool, 15(1).

[48] Schwartzberg, E. G., \& Tumlinson, J. H. (2014). Aphid honeydew alters plant defence responses. Functional Ecology, 28, 386-394.

[49] Sánchez-Sánchez, H., \& Morquecho-Contreras, A. (2017). Chemical plant defense against herbivores. In Herbivores. s.1.:Intech Open pp. 4 27.

[50] Stevens, M., \& Lacomme, C. (2018). Transmision of plant viruses. In R. H. Helmut F. van Emden (Eds.), Aphids as crop pest Oxfordshire: CAB International. Pp. 323-362.

[51] Thomas S., Boissot N., Vanlerberghe-Masutti F. et al. What do spring migrants reveal about sex and host selection in the melon aphid? BMC Evolutionary Biology. 2012;12(47).

[52] Tena A., Senft M, Desneux N., Dregni J. et al.The influence of aphidproduced honeydew on parasitoid fitness and nutritional state: A comparative study. Basic and applied ecology. 2018; 29.

[53] Uzest M., Gargani D., Dombrowsky, Cazevielle C, Cot D., Blanc S., et al. The "acrostyle": A newly described anatomical structure in aphid stylets. Arthropod structure and function. 2010; 39:221-229.

[54] Verdugo J. A., Francis F., Ramírez C. C. et al. A review on the complexity of insect-plant interactions under varying levels of resources and host resistance: the case of Myzus persicae-Prunus persica. Biotechnol. Agron. Soc. Environ. 2016;204(4):533-541.

[55] Walling, L. L. (2008). Avoiding effective defenses: Strategies employed by phloem-feeding insects. Plant Physiol, 146, 859-866.

[56] Werker, E. (2000). Trichome diversity and development. Advances in Botanical Research, 31,1-35.

[57] Will T., Furch A. C. U., Zimmermann M. R., et al. How PhloemFeeding insects face the challange of phloem-located defenses. Frontiers in Plant Science. 2013.

[58] Will, T., \& Van Bel, J. E. (2006) Physical and chemical interactions between aphids and plants. Journal of Experimental Botany, 57(4), 729-737.

[59] Wójcicka, A. (2015). Surface waxes as a plant defense barrier towards grain aphid. Acta Biologica Cracoviensia Series Botanica, 57(1), 95103.
[60] Wool, D. (2004). Galling aphids: specialization, biological complexity and variation. Annual Review of Entomology, 49,75-192.

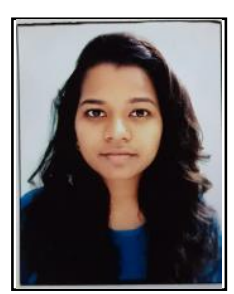

Kranti Kamlakar Waghmare is Research scholar in Environmental science.

She is a second university rank holder in her graduation. She has completed post- graduation in Environmental science from Savitribai Phule Pune University, Pune, India. She has published one review paper in international journal.

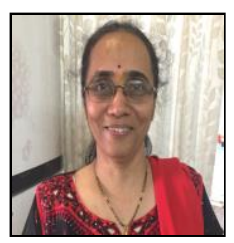

Prof. Dr. Ghayal Nivedita Amarendra is M.Sc. (1991), B.Ed. (1993), Ph.D. (2010) and SET from Savitribai Phule Pune University, Pune, Maharashtra, India. She was born In Pune on $12^{\text {th }}$ March 1967. She is presently working as Professor of Botany and research Mentor in Environmental sciences in Department of Botany, MES Abasaheb Garware College, Karve road, Pune - 411004. She has academic experience of 29 years and 17 years of Research experience. Her interests are in following research areas: Plant physiology, biochemistry, Allelopathy, ecology. she has published 32 research papers in national and international journals and 2 book chapters. She has completed 2 research projects in the research field of Allelopathy. She is Member of International Allelopathy Foundation.

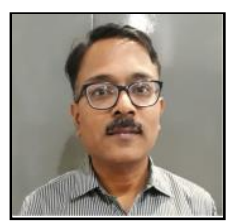

Dr. Mahesh Shindikar is an Assistant Professor of Biology in the Applied Science Department of College of Engineering Pune (Maharashtra, India). He has been instrumental in diverse activities of academic, research and administrative nature in the domain of biology and environmental sciences for the last two decades. 